\title{
Influence Factors for Community-Based Road Quality in Slum Settlement Areas
}

\author{
Mochammad Reyhan Firlandy ${ }^{1, a)}$, Hitapriya Suprayitno ${ }^{1, b)}$, Eko Budi Santoso $^{2, c)}$ \& Tri \\ Joko Wahyu Adi ${ }^{1, d)}$ \\ ${ }^{1)}$ Civil Engineering Department, Institut Teknologi Sepuluh Nopember (ITS), Surabaya \\ ${ }^{2)}$ Urban and Regional Planning Department., Institut Teknologi Sepuluh Nopember (ITS), Surabaya \\ Correspondance : ${ }^{a)}$ reyhanfirlandy@ gmail.com ${ }^{b}$ suprayitno.hita@gmail.com \\ ${ }^{c}$ eko_budi@urplan.its.ac.id \& ${ }^{d}$ tri_joko@ce.its.ac.id
}

\begin{abstract}
National Long-Term Development Plan (RPJPN) mandated to alleviate slum settlement areas until 0 hectares. One of the indicators to be assessed on slum settlement handling is by road settlement access. The quality of the road was affected by the physical condition and the operation, management factors either. This research aim is to identify factors that affected community-based settlement road management in slum settlement areas, through Kota Tanpa Kumuh (KOTAKU) Program or City Without Slum. The analysis used in this research is descriptive analysis, in which the researcher gathers factors related to community-based road management from literature study, also previous study and research. Then 7 experts that have expertise in slum alleviation subjects were chosen, to validate and filter the factors that have been gathered. The results indicate that there are 25 approved factors by all experts and considered as high influence factors, 13 factors approved by 4 - 6 experts considered as moderate influence factors, and 3 factors approved by less than 4 experts considered as low influence factors. This research contributes to Infrastructure Asset Management knowledge, specifically in communitybased infrastructure management.
\end{abstract}

Keywords : infrastructure management, community-based management road, influence factors, slum settlement areas, KOTAKU

\section{INTRODUCTION}

Mandated by National Long-Term Development Plan (RPJPN), slum settlement areas must alleviate to 0 hectares, and provide a livable and sustainable settlement. On slum settlement handling, there are 7 conditions to be assessed: one of them is settlement roads. Settlement roads can be built through contractual activity done by the contractor, or through community-based activity. The infrastructure always managed by an infrastructure management organization, in which there are knowledge related to management organization or infrastructure asset management (Suprayitno \& Soemitro, 2018). Community-based activity means that the community involved in management, starting from planning, construction, utilization, and maintenance phase. Road managed by the community is not entirely sustainable. This was seen from the assets of road that has been built in several areas, so there is a risk of making the areas back to be slum areas again.

The infrastructure function performance depends on its operational quality, while this operational quality depends on its physical condition, thus its maintenance quality (Suprayitno \& Soemitro, 2019). The quality of the road that has been built in slum areas was affected by physical condition and the operation, management factors either. The quality of the road determined the sustainability of the road. 
Community-based management factors also the key to infrastructure sustainability success. Each management phase, starting from planning, construction, utilization, and maintenance has its factors. Each factor has its nature as supporting or resisting performance, its strength of influence, its own easiness to be manipulated and its value (Suprayitno et al., 2019). This research will analyze the influence factors of community-based road management.

Community-based approach model captured the principle of developing social innovation to solve environmental problems and encourage involvement and engagement to get support from the wider community (Megawati et al., 2019). With this approach, the community gets involved in every phase of management, so the sense of belonging for the infrastructure that has been built could be better maintained.

According to Organization for Economic Corporation and Development (OECD; in Ayat, 2017), the infrastructure managed by the community is the infrastructure that used by themselves, also utilized and maintained based on their capacity. Therefore, the assets of roads that managed by the community depend on the efforts of the community itself in order to be well sustained and done according to their infrastructure asset management knowledge.

The needs for a good management effort in making a sustainable road are based on infrastructure asset management; which then become program or knowledge for infrastructure management necessary to continuously function properly, and as long as it is still needed economically, efficiently, effectively and meets green or sustainability principles (Soemitro \& Suprayitno, 2018).

Refering to Petunjuk Pelaksanaan KOTAKU Tingkat Kelurahan (Dit.PKP, 2018), one of the community-based infrastructure programs is KOTAKU Program (City Without Slum). Ministry of Public Works and Housing initiate KOTAKU to support slum settlement alleviation in 271 Cities/Districts in 34 Provinces in Indonesia. This community-based activity as community involvement effort in development, and to support poverty and unemployment alleviation.

Previous research has shown that community-based infrastructure activities have advantages and disadvantages to their management (Annisya \& Tantoro, 2017). Community involvement in management influenced by internal and external factors that will affect the result of infrastructure quality. The road quality is measured by its functional performance and its physical condition, in which the sustainability of function and physical condition is strongly considered (Suprayitno, et al, 2019).

Those affected factors to the result of infrastructure quality need to be defined. This research aims to identify the influence factors on community-based road management sustainability.

\section{RESEARCH METHOD}

Gathering variables in this research was done by literature studies related to communitybased road management, i.e. literature from government regulation, guidelines, and previous research (Dit.PKP 2018; Dit.PKP 2018a; Rahmaniyah, 2019). The researcher classifies the considered related variables starting from planning, construction, utilization, and maintenance phase. From this step, the researcher identified 41 variables that considered as influencing factors to community-based road management. The next step, i.e. involving experienced experts in the field of community-based slum settlement alleviation. In this stage, the researcher gathered the information through distributed questionnaire, where the experts can choose "agree" or "disagree" with the proposed variables related to the community-based road management. After the experts validate and filter the variables, the questionnaire results are analyzed using descriptive analysis, to describe which variables are considered has high, moderate or low influence on community-based road management, include its reasoning. 


\section{COLLECTING DATA}

In this research, 41 variables were identified by the researcher related to communitybased management infrastructure, especially settlement road. Those 41 variables are divided into 5 phases of infrastructure management, i.e. planning, construction, utilization, maintenance, and expected results. The variables gathered from several previous research, literature study, and KOTAKU guidelines. The 41 variables are presented in Table 1.

Table 1. Community-Based Road Management Variables

\begin{tabular}{|c|c|c|c|}
\hline No & Phases & & Factors \\
\hline \multirow{10}{*}{1} & \multirow{10}{*}{ Planning } & 1 & Program implementation socialization \\
\hline & & 2 & Attendance in the planning meeting \\
\hline & & 3 & Community involvement in submissions of activity proposals \\
\hline & & 4 & Community participation in construction activity decision-making \\
\hline & & 5 & Lurah or Head of Village (Kepala Desa) Involvement \\
\hline & & 6 & Board of Trustee (Badan Keswadayaan Masyarakat/BKM) activeness \\
\hline & & 7 & Facilitator activeness \\
\hline & & 8 & Woman contribution in the planning phase \\
\hline & & 9 & Critical issues reflection and social mapping \\
\hline & & 10 & City-level consultation forum \\
\hline \multirow{10}{*}{2} & \multirow{10}{*}{ Construction } & 1 & Community involvement in the construction phase \\
\hline & & 2 & Community sharing in construction topics \\
\hline & & 3 & Availability of tools and materials resources \\
\hline & & 4 & Implementation based on Procedure and Operational Standard \\
\hline & & 5 & Self Help Group capacity strengthening \\
\hline & & 6 & Assistance by the facilitator in the construction phase \\
\hline & & 7 & Understanding level of community in the construction phase \\
\hline & & 8 & Woman participation in the construction phase \\
\hline & & 9 & Technology used \\
\hline & & 10 & Post road construction certification \\
\hline \multirow{6}{*}{3} & \multirow{6}{*}{ Utilization } & 1 & Shared rules \\
\hline & & 2 & The road functioning volunteer supervision team \\
\hline & & 3 & The existence of institutionalized KPP \\
\hline & & 4 & Coordination with government \\
\hline & & 5 & Management of infrastructure operational work programs \\
\hline & & 6 & Road inventory \\
\hline \multirow{10}{*}{4} & \multirow{10}{*}{ Maintenance } & 1 & Functioning of KPP \\
\hline & & 2 & Kelurahan/Village government contribution \\
\hline & & 3 & Facilitator role in the maintenance \\
\hline & & 4 & Community sharing in maintenance \\
\hline & & 5 & Partnership and assistance in maintenance financing \\
\hline & & 6 & Road maintenance methods \\
\hline & & 7 & Woman contribution to maintenance \\
\hline & & 8 & Community awareness and motivation in maintenance \\
\hline & & 9 & Road supervision \\
\hline & & 10 & Regular reports \\
\hline \multirow{5}{*}{5} & \multirow{5}{*}{ Results } & 1 & Good quality and functioning roads \\
\hline & & 2 & The road can be utilized for a long time \\
\hline & & 3 & The existence and functioning of KPP at Kelurahan/Village level \\
\hline & & 4 & Source of funding for road maintenance \\
\hline & & 5 & Satisfaction level of community \\
\hline
\end{tabular}




\section{RESEARCH ANALYSIS}

\section{Variables Filter and Validation by Experts}

In the questionnaire, the respondents were given operational definition to each factor, so experts understanding in interpret the factor are similar. Each factor will provide a choice of "agree" and "disagree", each expert will choose their answer based on their opinion relate to their own knowledge and experience. This research involves 7 experts by purposive sampling, which is the research sample selection method with some criteria to get clear and more representable data. The selection criteria for the researchers are the experts are (1) involve as an actor in KOTAKU; (2) experienced and expert in slum settlement alleviation field; (3) having knowledge related to community-based infrastructure. Based on these criteria, the experts that selected are described in Table 2 as follows:

Table 2. Experts as Respondents

\begin{tabular}{|c|l|c|}
\hline Num. & \multicolumn{1}{|c|}{ Institution } & Total \\
\hline 1 & PMU of KOTAKU (NSUP and NUSP-2) & 1 Person \\
\hline 2 & $\begin{array}{l}\text { PIU of Community Based Settlement } \\
\text { Development }\end{array}$ & 2 Persons \\
\hline 3 & $\begin{array}{l}\text { Settlement Facility Agency of East Java } \\
\text { Province }\end{array}$ & 1 Person \\
\hline 4 & $\begin{array}{l}\text { Settlement and Housing Agency of Malang } \\
\text { City }\end{array}$ & 1 Person \\
\hline 5 & OSP KOTAKU of East Java Province & 1 Person \\
\hline 6 & $\begin{array}{l}\text { Coordinator City KOTAKU Team of } \\
\text { Malang City }\end{array}$ \\
\hline
\end{tabular}

The task of each expert is to choose "agree" or "disagree" by considering these factors give influences to the community-based road management or not. The experts also could give the reason to be considered for each answer.

\section{Factor Selection Results Analysis}

Descriptive analysis will be used to describe the results of the questionnaire, by describing the experts answer thoroughly. For the 41 variables submitted to experts, using Likert scale, there will be 3 variable grouping based on determined range, i.e. the high, moderate and low importance level of community-based road management influence factors. As for the results of the questionnaire as described in Table 3 follows (for more detail in Appendix 1): 
Table 3. Expert Questionnaire Results Summary

\begin{tabular}{|c|c|c|c|c|}
\hline No & Phases & & Factors & $\begin{array}{c}\text { The } \\
\text { Number of } \\
\text { Agreed } \\
\text { Experts }\end{array}$ \\
\hline \multirow{10}{*}{1} & \multirow{10}{*}{ Planning } & 1 & Program implementation socialization & 7 \\
\hline & & 2 & Attendance in the planning meeting & 7 \\
\hline & & 3 & $\begin{array}{l}\text { Community involvement in submissions of activity } \\
\text { proposals }\end{array}$ & 2 \\
\hline & & 4 & $\begin{array}{l}\text { Community participation in construction activity decision- } \\
\text { making }\end{array}$ & 6 \\
\hline & & 5 & Lurah or Head of Village (Kepala Desa) Involvement & 7 \\
\hline & & 6 & $\begin{array}{l}\text { Board of Trustee (Badan Keswadayaan Masyarakat/BKM) } \\
\text { activeness }\end{array}$ & 7 \\
\hline & & 7 & Facilitator activeness & 7 \\
\hline & & 8 & Woman contribution in the planning phase & 7 \\
\hline & & 9 & Critical issues reflection and social mapping & 7 \\
\hline & & 10 & City-level consultation forum & 6 \\
\hline \multirow{10}{*}{2} & \multirow{10}{*}{ Construction } & 11 & Community involvement in the construction phase & 7 \\
\hline & & 12 & Community sharing in the construction & 7 \\
\hline & & 13 & Availability of tools and materials resources & 2 \\
\hline & & 14 & $\begin{array}{l}\text { Implementation based on Procedure and Operational } \\
\text { Standard }\end{array}$ & 7 \\
\hline & & 15 & Self Help Group capacity strengthening & 7 \\
\hline & & 16 & Assistance by the facilitator in the construction phase & 7 \\
\hline & & 17 & Understanding level of community in construction phase & 7 \\
\hline & & 18 & Woman participation in the construction phase & 6 \\
\hline & & 19 & Technology used & 6 \\
\hline & & 20 & Post road construction certification & 6 \\
\hline \multirow{6}{*}{3} & \multirow{6}{*}{ Utilization } & 21 & Shared rules & 7 \\
\hline & & 22 & The road functioning volunteer supervision team & 6 \\
\hline & & 23 & The existence of institutionalized KPP & 7 \\
\hline & & 24 & Coordination with government & 7 \\
\hline & & 25 & Management of infrastructure operational work programs & 6 \\
\hline & & 26 & Road inventory & 6 \\
\hline \multirow{10}{*}{4} & \multirow{10}{*}{ Maintenance } & 27 & Functioning of KPP & 7 \\
\hline & & 28 & Kelurahan/Village government contribution & 7 \\
\hline & & 29 & Facilitator role in maintenance & 2 \\
\hline & & 30 & Community sharing in maintenance & 6 \\
\hline & & 31 & Partnership and assistance in maintenance financing & 5 \\
\hline & & 32 & Road maintenance methods & 7 \\
\hline & & 33 & Woman contribution to maintenance & 6 \\
\hline & & 34 & Community awareness and motivation in maintenance & 7 \\
\hline & & 35 & Road supervision & 7 \\
\hline & & 36 & Regular reports & 7 \\
\hline \multirow{5}{*}{5} & \multirow{5}{*}{ Results } & 37 & Good quality and functioning roads & 7 \\
\hline & & 38 & The road can be utilized for a long time & 6 \\
\hline & & 39 & $\begin{array}{l}\text { The existence and functioning of KPP at Kelurahan/Village } \\
\text { level }\end{array}$ & 7 \\
\hline & & 40 & Source of funding for road maintenance & 7 \\
\hline & & 41 & Satisfaction level of community & 6 \\
\hline
\end{tabular}


Based on the table above, there are three variables grouping as community-based road management factor, i.e. high importance factors, where the factors approved by 7 experts, moderate importance factors, where the factors approved by 4 - 6 experts and low importance factors, where the factors approved by less than 4 experts. For the agreed factors, the experts didn't give the reason on it, so in high importance factor group, there will be no reason on the table, which can be explained as follow :

\section{High Importance Factor}

The High Importance Factors, i.e. 25 variables agreed by all experts as influence factors are considered as factors with high importance level. As explained above, for the agreed factors, the experts didn't give its reason, so this table shown only selected factors, because all of the experts agree to the factors. These are presented in the Table 4.

Table 4. High Importance Level of Community-Based Road Management Influence Factors

\begin{tabular}{|c|c|c|c|c|c|}
\hline No & Phases & Factors & No & Phases & Factors \\
\hline 1 & \multirow{7}{*}{ Planning } & $\begin{array}{l}\text { Program implementation } \\
\text { socialization }\end{array}$ & 14 & \multirow{3}{*}{ Utilization } & Shared rules \\
\hline 2 & & $\begin{array}{l}\text { Attendance in the planning } \\
\text { meeting }\end{array}$ & 15 & & $\begin{array}{l}\text { The existence of institutionalized } \\
\text { KPP }\end{array}$ \\
\hline 3 & & $\begin{array}{l}\text { Lurah or Head of Village } \\
\text { (Kepala Desa) Involvement }\end{array}$ & 16 & & Coordination with government \\
\hline 4 & & $\begin{array}{l}\text { Board of Trustee (Badan } \\
\text { Keswadayaan } \\
\text { Masyarakat/BKM) } \\
\text { activeness }\end{array}$ & 17 & \multirow{6}{*}{ Maintenance } & Functioning of KPP \\
\hline 5 & & Facilitator activeness & 18 & & $\begin{array}{l}\text { Kelurahan/Village government } \\
\text { contribution }\end{array}$ \\
\hline 6 & & $\begin{array}{l}\text { Woman contribution in } \\
\text { planning phase }\end{array}$ & 19 & & Road maintenance methods \\
\hline 7 & & $\begin{array}{l}\text { Critical issues reflection and } \\
\text { social mapping }\end{array}$ & 20 & & $\begin{array}{l}\text { Community awareness and } \\
\text { motivation in maintenance }\end{array}$ \\
\hline 8 & \multirow{6}{*}{ Construction } & $\begin{array}{l}\text { Community involvement in } \\
\text { the construction phase }\end{array}$ & 21 & & Road supervision \\
\hline 9 & & $\begin{array}{l}\text { Community sharing in the } \\
\text { construction }\end{array}$ & 22 & & Regular reports \\
\hline 10 & & $\begin{array}{l}\text { Implementation based on } \\
\text { Procedure and Operational } \\
\text { Standard }\end{array}$ & 23 & \multirow{3}{*}{ Results } & $\begin{array}{l}\text { Good quality and functioning } \\
\text { roads }\end{array}$ \\
\hline 11 & & $\begin{array}{l}\text { Self Help Group capacity } \\
\text { strengthening }\end{array}$ & 24 & & $\begin{array}{l}\text { The existence and functioning of } \\
\text { KPP at Kelurahan/Village level }\end{array}$ \\
\hline 12 & & $\begin{array}{l}\text { Assistance by the facilitator } \\
\text { in the construction phase }\end{array}$ & 25 & & $\begin{array}{l}\text { Source of funding for road } \\
\text { maintenance }\end{array}$ \\
\hline 13 & & $\begin{array}{l}\text { Understanding level of } \\
\text { community in the } \\
\text { construction phase }\end{array}$ & & & \\
\hline
\end{tabular}




\section{Moderate Importance Factors}

The moderate importance factors, i.e. 13 variables that agreed by $4-6$ experts as influence factor in community-based road management, considered as factors with moderate importance level. These are presented in Table 5.

Table 5. Moderate Importance Level of Community-Based Road Management Influence Factors

\begin{tabular}{|c|c|c|c|}
\hline No & Phases & Factors & Reasons \\
\hline 1 & Planning & $\begin{array}{l}\text { Community } \\
\text { participation in } \\
\text { construction activity } \\
\text { decision-making }\end{array}$ & $\begin{array}{l}\text { In the decision-making process, it is better not to } \\
\text { involve many parties, only those who have interest } \\
\text { but should represent input from community }\end{array}$ \\
\hline 2 & \multirow{4}{*}{ Construction } & $\begin{array}{l}\text { City-level } \\
\text { consultation forum }\end{array}$ & $\begin{array}{l}\text { The one who plays more important role is the } \\
\text { city/district level government as lead actor in the } \\
\text { development }\end{array}$ \\
\hline 3 & & $\begin{array}{l}\text { Woman participation } \\
\text { in the construction } \\
\text { phase }\end{array}$ & $\begin{array}{l}\text { In the onstruction phase, woman role does not really } \\
\text { need to exist }\end{array}$ \\
\hline 4 & & Technology used & $\begin{array}{l}\text { The chosen technology is not always a simple one, } \\
\text { because it will determine quality, pace, and } \\
\text { accuracy of construction }\end{array}$ \\
\hline 5 & & $\begin{array}{l}\text { Post road } \\
\text { construction } \\
\text { certification }\end{array}$ & $\begin{array}{l}\text { In the implementation, not all of the works could be } \\
\text { certified to ensure road quality }\end{array}$ \\
\hline 6 & \multirow{3}{*}{ Utilization } & $\begin{array}{l}\text { The road functioning } \\
\text { volunteer } \\
\text { supervision team }\end{array}$ & $\begin{array}{l}\text { This role is the responsibility of KPP, so it is not } \\
\text { important to create a new team }\end{array}$ \\
\hline 7 & & $\begin{array}{l}\text { Management of } \\
\text { infrastructure } \\
\text { operational work } \\
\text { programs }\end{array}$ & $\begin{array}{l}\text { Road utilization works programs are always } \\
\text { changing (flexible) in the field }\end{array}$ \\
\hline 8 & & Road inventory & $\begin{array}{l}\text { Inventory has been always the job of the local } \\
\text { government, so it is not the main factor of } \\
\text { community-based road management }\end{array}$ \\
\hline 9 & \multirow{3}{*}{ Maintenance } & $\begin{array}{l}\text { Community sharing } \\
\text { in maintenance }\end{array}$ & $\begin{array}{l}\text { It is a good thing and easier way if the community is } \\
\text { being proactive in the community sharing for public } \\
\text { interests, but needs to be support only, so the } \\
\text { community are aware of their rights from } \\
\text { Kelurahan/Villages government level program }\end{array}$ \\
\hline 10 & & $\begin{array}{l}\text { Partnership and } \\
\text { assistance in } \\
\text { maintenance } \\
\text { financing }\end{array}$ & $\begin{array}{l}\text { The partnership, which is conducted especially with } \\
\text { private sectors, are better for main works that has } \\
\text { numerous costs and the result of changes are more } \\
\text { visible, the cost for maintenance and improvement } \\
\text { susceptible to be misused }\end{array}$ \\
\hline 11 & & $\begin{array}{l}\text { Woman contribution } \\
\text { to maintenance }\end{array}$ & $\begin{array}{l}\text { Woman tend to only carry out minor maintenance } \\
\text { works }\end{array}$ \\
\hline 12 & \multirow[t]{2}{*}{ Results } & $\begin{array}{l}\text { The road can be } \\
\text { utilized for a long } \\
\text { time }\end{array}$ & $\begin{array}{l}\text { On this factor, there are more inluencing factors, not } \\
\text { only community internal factor in road maintenance }\end{array}$ \\
\hline 13 & & $\begin{array}{l}\text { Satisfaction level of } \\
\text { community }\end{array}$ & $\begin{array}{l}\text { It cannot be a measurement, because satisfaction } \\
\text { doesn't mean that they involved in the management. }\end{array}$ \\
\hline
\end{tabular}


3. Low Impotance Factors

The low importance factors, i.e. 3 variables that agreed by less than 4 experts as influence factors in community-based road management, on this research considered as factors with low importance level $(0-3$ points). These are presented in Table 6 .

Table 6. Low Importance Level of Community-Based Road Management Influence Factors

\begin{tabular}{|c|l|l|l|}
\hline No & \multicolumn{1}{|c|}{ Phases } & \multicolumn{1}{|c|}{ Factors } & \multicolumn{1}{c|}{ Reasons } \\
\hline 1 & Planning & $\begin{array}{l}\text { Community } \\
\text { involvement in } \\
\text { submissions of } \\
\text { activity proposals }\end{array}$ & $\begin{array}{l}\text { Proposals are based on needs, urgency, and } \\
\text { determinate budget on arranging activity. }\end{array}$ \\
\hline 2 & Construction & $\begin{array}{l}\text { Availability of tools } \\
\text { and materials } \\
\text { resources }\end{array}$ & $\begin{array}{l}\text { Tools and materials resources still can be supplied, } \\
\text { although it must be taken from another area, with } \\
\text { additional cost }\end{array}$ \\
\hline 3 & Maintenance & $\begin{array}{l}\text { Facilitator role in } \\
\text { maintenance }\end{array}$ & $\begin{array}{l}\text { Facilitators expected to brief and assist on the first } \\
\text { phase, so Kelurahan/Villages officials and the } \\
\text { community can become more independent and } \\
\text { empowered to implement road maintenance activity } \\
\text { also the uncertainty of facilitator contract) }\end{array}$ \\
\hline
\end{tabular}

\section{CONCLUSION}

The results of this research obtained 41 variables rated that influencing community-based road management with different level of importance. To see the importance level of the factors, its divided into 3 groups. The first group is the factors considered as high importance level factors, it consists of 25 factors, divided as follows: 7 factors in planning phase, 6 factors in construction phase, 3 factors in utilitazion phase, 6 factors in maintenance phase, and 3 factors in results phase. The second group is the factors considered as moderate importance level of factor, it consists of 13 factors, divided as follows: 1 factor in planning phase, 4 factors in construction phase, 3 factors in utilitazion phase, 3 factors in maintenance phase, and 2 factors in results phase. The third group is the factors considered as low importance level factors, it consists of 3 factors, divided as follows: 1 factor in planning phase, 1 factor in construction phase, and 1 factor in maintenance phase.

This research gathered variables only from KOTAKU's guidelines and one of the previous research in Civil Engineering Department of Institut Teknologi Sepuluh Nopember, and the chosen experts determined by purposive sampling. From these research results, it possible that there are still many factors related to community-based infrastructure management, if this research plan to be developed, its need to add more variables from several literatures.

\section{REFERENCES}

Anissya, Nur, \& Tantoro, Swis. (2017). "Partisipasi Masyarakat Terhadap Pembangunan Infrastruktur di Desa Sungai Pinang Kecamatan Hulu Kuantan Kabupaten Kuantan Singingi Provinsi Riau”. Jurnal Online Mahasiswa Fakultas Ilmu Sosial dan Ilmu Politik Universitas Riau, Vol. 4, No. 2, Oktober 2017, Hal. 1 - 15.

Ayat, Muhammad. (2016). Studi Peningkatan Kualitas Prasarana Dasar Lingkungan Permukiman di Kota Sinjai. Tesis. Teknik Perencanaan Wilayah Kota. Universitas Islam Negeri Alauddin. Makassar 
Dit.PKP (2018). “Petunjuk Pelaksanaan KOTAKU Tingkat Kelurahan”. Direktorat Pengembangan Kawasan Permukiman, Direktorat Jenderal Cipta Karya, Kementerian Pekerjaan Umum dan Perumahan Rakyat. Jakarta.

Dit.PKP (2018a). "Prosedur Operasional Standar Operasional dan Pemeliharaan Program KOTAKU”. Direktorat Pengembangan Kawasan Permukiman, Direktorat Jenderal Cipta Karya, Kementerian Pekerjaan Umum dan Perumahan Rakyat. Jakarta

Megawati, Veny, Pratono, A. H., Mulya, T. W. \& Prima, D. A. (2019). "Community Based Enterprise: A Business Model for Asset and Infrastructrue Model”. Jurnal Manajemen Aset Infrastruktur \& Fasilitas, Vol. 3, No. 2, September 2019, Hal. 109 - 118.

Rahmaniyah, Ayu. (2019). Faktor Prioritas Dalam Keberlanjutan Fungsi Jalan Lingkungan Dengan Pengelolaan Berbasis Masyarakat Pada Permukiman Kumuh di Kota Pasuruan. Tesis Master. Departemen Teknik Sipil. Institut Teknologi Sepuluh Nopember. Surabaya Soemitro, Ria Asih Aryani \& Suprayitno, Hitapriya. (2018). "Preliminary Reflexion on Basic Concept of Facility Asset Management". Jurnal Manajemen Aset Infrastruktur \& Fasilitas, Vol. 2, Sup. 1, Juni 2018, Hal. 01 - 14.

Suprayitno, Hitapriya \& Soemitro, Ria Asih Aryani. (2018). "Preliminary Reflexion on Basic Principal of Infrastructure Asset Management". Jurnal Manajemen Aset Infrastruktur \& Fasilitas, Vol. 2, No. 1, Maret 2018, Hal 01 - 10.

Suprayitno, H., Rahmaniyah, A., Santoso, E. B. (2019). "Preliminary Analysis on The Success of Community-based Community Road Program Related to Community Characteristics in Pasuruan City". WUIACE 2019.

Suprayitno, Hitapriya \& Soemitro, Ria Asih Aryani. (2019). "Reflection on Basic View of Public Infrastructure for Infrastructure Asset Management in Indonesia". Jurnal Manajemen Aset Infrastruktur \& Fasilitas, Vol. 3, Sup. 1, Juni 2019, Hal. 15 - 24.

Suprayitno, H., Soemitro, R. A. A., Maulana, M. A. \& Hesna, Y. (2019). "Preliminary Reflection on Performance Indicator and Performance Factor for Infrastructure Asset Management”. Journal of Infrastructure \& Facility Asset Managemjent, Vol. 2, Issue 1, March 2020. 


\section{Appendix}

\section{Expert Questionnaire Result Detail}

\begin{tabular}{|c|c|c|c|c|c|c|c|c|}
\hline No & Factors & R1 & $\mathbf{R 2}$ & $\mathbf{R 3}$ & R4 & $\mathbf{R 5}$ & R6 & R7 \\
\hline 1 & Program implementation socialization & A & A & A & A & A & A & A \\
\hline 2 & Attendance in planning meeting & A & A & A & A & A & A & A \\
\hline 3 & $\begin{array}{l}\text { Community involvement in submissions of } \\
\text { activity proposals }\end{array}$ & $\mathrm{D}$ & $\mathrm{D}$ & A & A & $\mathrm{D}$ & $\mathrm{D}$ & $\mathrm{D}$ \\
\hline 4 & $\begin{array}{l}\text { Community participation in construction } \\
\text { activity decision-making }\end{array}$ & A & A & A & $\mathrm{D}$ & A & A & A \\
\hline 5 & $\begin{array}{l}\text { Lurah or Head of Village (Kepala Desa) } \\
\text { Involvement }\end{array}$ & A & A & A & A & A & A & A \\
\hline 6 & $\begin{array}{l}\text { Board of Trustee (Badan Keswadayaan } \\
\text { Masyarakat/BKM) activeness }\end{array}$ & A & A & A & A & A & A & A \\
\hline 7 & Facilitator activeness & A & A & A & A & A & A & A \\
\hline 8 & Woman contribution in planning phase & A & A & A & A & A & A & A \\
\hline 9 & Critical issues reflection and social mapping & A & A & A & A & A & A & A \\
\hline 10 & City level consultation forum & A & A & $\mathrm{D}$ & A & A & A & A \\
\hline 11 & $\begin{array}{l}\text { Community involvement in construction } \\
\text { phase }\end{array}$ & A & A & A & A & A & A & A \\
\hline 12 & Community sharing in construction & A & A & A & A & A & A & A \\
\hline 13 & Availability of tools and materials resources & A & $\mathrm{D}$ & $\mathrm{D}$ & $\mathrm{D}$ & $\mathrm{D}$ & A & $\mathrm{D}$ \\
\hline 14 & $\begin{array}{l}\text { Implementation based on Procedure and } \\
\text { Operational Standard }\end{array}$ & A & A & A & A & A & A & A \\
\hline 15 & Self Help Group capacity strengthening & A & A & A & A & A & A & A \\
\hline 16 & Assistance by facilitator in construction phase & A & A & A & A & A & A & A \\
\hline 17 & $\begin{array}{l}\text { Understanding level of community in } \\
\text { construction phase }\end{array}$ & A & A & A & A & A & A & A \\
\hline 18 & Woman participation in construction phase & A & A & $\mathrm{D}$ & A & A & A & A \\
\hline
\end{tabular}




\begin{tabular}{|c|c|c|c|c|c|c|c|c|}
\hline No & Factors & $\mathbf{R} 1$ & $\mathbf{R 2}$ & $\mathbf{R 3}$ & R4 & R5 & R6 & $\mathbf{R 7}$ \\
\hline 19 & Technology used & A & A & A & A & A & $\mathrm{D}$ & A \\
\hline 20 & Post road construction certification & A & A & $\mathrm{D}$ & A & A & A & A \\
\hline 21 & Shared rules & A & A & A & $\mathrm{A}$ & A & A & A \\
\hline 22 & $\begin{array}{l}\text { The road functioning volunteer supervision } \\
\text { team }\end{array}$ & A & A & A & $\mathrm{D}$ & A & $\mathrm{A}$ & A \\
\hline 23 & The existence of institutionalized KPP & A & A & A & A & A & A & A \\
\hline 24 & Coordination with government & A & A & A & A & A & A & A \\
\hline 25 & $\begin{array}{l}\text { Management of infrastructure operational } \\
\text { work programs }\end{array}$ & A & A & A & A & $\mathrm{D}$ & A & A \\
\hline 26 & Road inventory & A & A & $\mathrm{D}$ & A & A & A & A \\
\hline 27 & Functioning of KPP & A & A & $\mathrm{A}$ & A & A & $\mathrm{A}$ & A \\
\hline 28 & Kelurahan/Village government contribution & A & A & A & A & A & A & A \\
\hline 29 & Facilitator role in maintenance & $\mathrm{D}$ & $\mathrm{D}$ & A & $\mathrm{D}$ & A & $\mathrm{D}$ & $\mathrm{D}$ \\
\hline 30 & Community sharing in maintenance & A & A & A & $\mathrm{D}$ & A & A & A \\
\hline 31 & $\begin{array}{l}\text { Partnership and assistance in maintenance } \\
\text { financing }\end{array}$ & A & $\mathrm{D}$ & $\mathrm{A}$ & $\mathrm{D}$ & A & A & A \\
\hline 32 & Road maintenance methods & A & A & A & A & A & A & A \\
\hline 33 & Woman contribution in maintenance & A & A & $\mathrm{D}$ & A & A & A & A \\
\hline 34 & $\begin{array}{l}\text { Community awareness and motivation in } \\
\text { maintenance }\end{array}$ & A & A & A & A & A & A & A \\
\hline 35 & Road supervision & A & A & A & A & A & A & A \\
\hline 36 & Regular reports & A & A & A & A & A & $\mathrm{A}$ & A \\
\hline 37 & Good quality and functioning roads & A & A & A & A & A & A & A \\
\hline 38 & The road can be utilized for a long time & A & A & A & $\mathrm{D}$ & A & A & A \\
\hline
\end{tabular}


e)ISSN 2656-8896 (p)ISSN 2656-890X

Journal of Infrastructure and Facility Asset Management - Vol. 2, Issue. 2, September 2020

\begin{tabular}{|c|l|c|c|c|c|c|c|c|}
\hline No & \multicolumn{1}{|c|}{ Factors } & R1 & R2 & R3 & R4 & R5 & R6 & R7 \\
\hline 39 & $\begin{array}{l}\text { The existence and functioning of KPP at } \\
\text { Kelurahan/Village level }\end{array}$ & A & A & A & A & A & A & A \\
\hline 40 & Source of funding for road maintenance & A & A & A & A & A & A & A \\
\hline 41 & Satisfaction level of community & A & A & D & A & A & A & A \\
\hline
\end{tabular}

